\title{
Forage yield of Urochloa cultivars in a warm sub-humid environment
}

Robles-Vega F.J. ${ }^{1}$, Granados-Rivera L.D. ${ }^{2}$, Joaquín-Cancino S. ${ }^{3}$, Aguado-Lara G. ${ }^{1}$, Rivas-Jacobo M.A. ${ }^{4}$. Garay-Martínez J.R. ${ }^{5 *}$

${ }^{1}$ Instituto Tecnológico de Huejutla, Tecnológico Nacional de México. Carretera HuejutlaChalahuiyapa, Km 5.5, Huejutla de Reyes, Hidalgo, México. ${ }^{2}$ Instituto Nacional de Investigaciones Forestales, Agrícolas y Pecuarias, Campo Experimental General Terán. ${ }^{3}$ Universidad Autónoma de Tamaulipas, Facultad de Ingeniería y Ciencias. Ciudad Victoria, Tamaulipas, México. ${ }^{4}$ Universidad Autónoma de San Luis Potosí, Facultad de Agronomía y Veterinaria, Soledad de Graciano Sánchez, San Luis Potosí. ${ }^{5}$ Instituto Nacional de Investigaciones Forestales, Agrícolas y Pecuarias, Campo Experimental Las Huastecas, Altamira, Tamaulipas, México.

*Corresponding Author: garay.jonathan@inifap.gob.mx

\begin{abstract}
Objective: To evaluate for 10 weeks the growth of five Urochloa cultivars: Camello, Cobra, Cayman, Convert 330, Mavuno and Xaraés; during the North Winds (NS), Dry (DS) and Rainy (RS) seasons in a warm sub-humid environment.

Design/Methodology/Approach: The variables were crop growth rate (CGR; $\mathrm{kg} \mathrm{ha}^{-1} \mathrm{~d}^{-1}$ ) and total dry matter yield (TDM: $\mathrm{t} \mathrm{ha}^{-1}$ ); which were analyzed under a completely randomized design (Tukey; $p=0.05$ ).

Results: During NS, Mavuno and Xaraés presented, on average, the highest values of CGR (p<0.05), 23.7 and $19.4 \mathrm{~kg} \mathrm{ha}^{-1}$ $d^{-1}$, respectively. In DS the cultivars Xaraés, Convert 330, Mavuno, and Cayman presented the highest values, with 20.7 and $26.8 \mathrm{~kg} \mathrm{ha}^{-1} \mathrm{~d}^{-1}$, in week 2 and 4, respectively. During RS, in the second and fourth week of regrowth, the Xaraés and Mavuno cultivars presented the highest CGR (p<0.05), 119.8 and $144.7 \mathrm{~kg} \mathrm{ha}^{-1} \mathrm{~d}^{-1}$, on average. In the NS, the Mavuno hybrid presented the highest yields $(p<0.05)$ of TDM, 0.886, 1.553 and $2.156 \mathrm{t} \mathrm{ha}^{-1}$ in week 6,8 and 10 , respectively. For RS, the cultivars Camello, Cayman, Mavuno, and Xaraés presented similar yields of TDM; which, on average, were 4.652 , 5.312 and $6.278 \mathrm{tha}^{-1}$, at 6, 8 and 10 weeks, respectively.
\end{abstract}

Findings/Conclusions: The cultivars Xaraés, Mavuno and Cayman presented good forage potential in a warm sub-humid environment; mainly for showing greater growth and accumulation of total dry matter.

\section{INTRODUCTION}

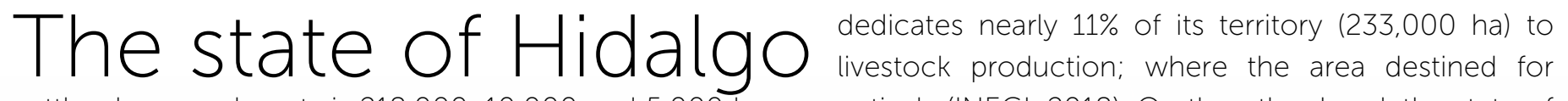
cattle, sheep and goats is $218,000,10,000$ and 5,000 ha, respectively (INEGI, 2018). On the other hand, the state of Veracruz dedicates about 3.4 million ha (48\% of the state territory) to livestock, where $99 \%$ of the surface is for bovine

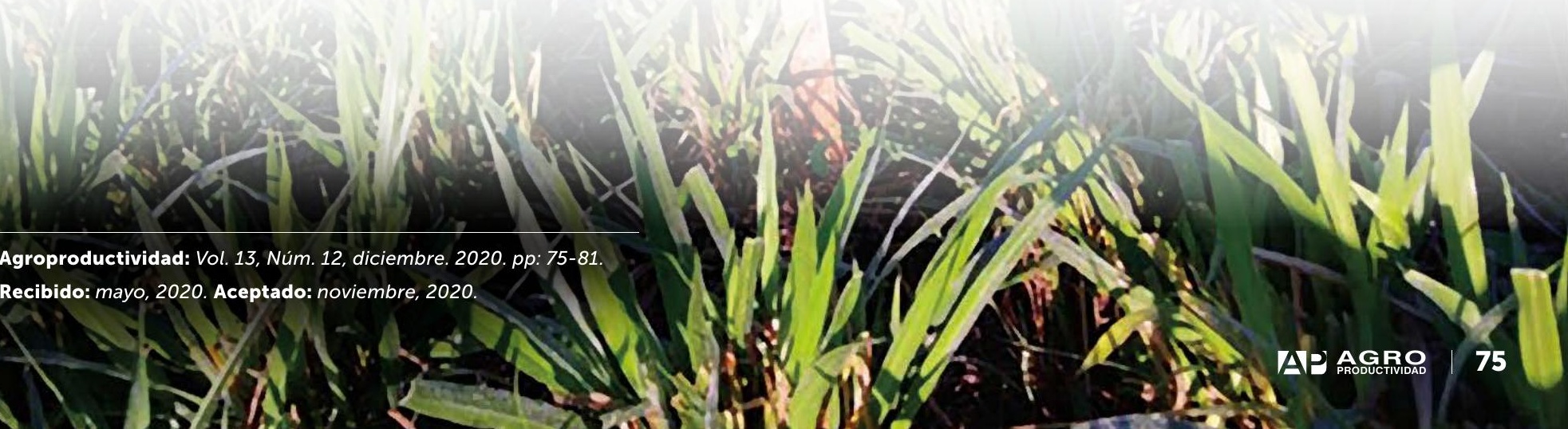


production (INEGI, 2018). Both states have a livestock vocation, and in addition, they share a territorial limit and therefore the climatic conditions in the northeast of Hidalgo and north of Veracruz are similar. In this region, the climate is semi-warm with abundant rains in summer ( $>1,200 \mathrm{~mm}$ per year) and temperatures above $15^{\circ} \mathrm{C}$ (INEGI, 2017), conditions that allow tropical forage grasses to present high growth rates, which is reflected in higher forage yield (Santos et al. 2014). However, animal production is affected by the variation in forage yield during the year, since there is a shortage during the dry season and surpluses in the rainy season.

In the humid tropical region there are three well-defined seasons: the rainy season, when the precipitation is greater and together with the temperature they contribute to the active growth of forages; the dry season, when the yield is drastically affected by hydric stress due to lack of water in the soil; and the north winds season, when there is high cloudiness and a decrease in temperature, so the growth of tropical species is affected (Hernández et al., 1990; Martínez et al., 2008). Photosynthesis and the accumulation of dry matter are closely associated with photosynthetically active radiation (Mishra et al., 2010), so that cloudiness could affect these processes; in addition to this, the minimum threshold temperature of most tropical grasses is 15 ${ }^{\circ} \mathrm{C}$ (Berone, 2016), although some Urochloa cultivars such as Xaraés and Insurgente have lower minimum threshold temperature, 12.4 and $10.5{ }^{\circ} \mathrm{C}$, respectively (Silva et al., 2012).

The forage yield of Urochloa cultivars ranges between 11 and 15 t ha $^{-1}$ year $^{-1}$ and said production is not constant throughout the year, since it depends mainly on environmental conditions (Garay et al., 2017); therefore, the annual forage yield is presented at 72,18 and $10 \%$, during the rainy, north winds and dry seasons, respectively (Martínez et al., 2008). It has been reported that the most recent hybrids of the genus Urochloa present greater potential for forage production and higher nutritional value (protein and digestibility) (Pizarro et al., 2013; Vendramini et al., 2014). It is important that before introducing a new forage material to any production system, the productive behavior should be evaluated in a controlled manner to determine if it is an option for livestock production in the region. Therefore, the objective of this study was to evaluate the dynamics of forage growth and production of Urochloa cultivars in the north winds, dry and rainy seasons in a warm subhumid environment

\section{MATERIALS AND METHODS}

\section{Location of the Experimental Site and Climatic Characteristics}

The study was carried out in seasonal conditions from November 2018 to August 2019, at the Huejutla Technological Institute, located on the HuejutlaChalahuiyapa Highway, km 5.5. Huejutla de Reyes, Hidalgo, Mexico. The geographical coordinates are $21^{\circ}$ 9' 19.66" N and 98 22' 11.02" W, at 112 meters above sea level. The climate is classified as warm sub-humid $\left[A x_{2}\left(x^{\prime}\right)\right.$; García, 2004] with abundant summer rains mean annual temperature that ranges between 24 and $26^{\circ} \mathrm{C}$ (INEGI, 2017). In this place there are three well-defined seasons: dry, rainy, and north winds (Figure 1; SMN, 2020).

\section{Treatments and Management of the Experimental Plots}

The evaluated treatments (cultivars) were five hybrids of Urochloa: Camello, Cobra, Cayman, Convert 330 and Mavuno, and one variety ( $U$. brizantha cv. Xaraés). They were evaluated for 10 weeks during the north winds, dry and rainy seasons. These cultivars were sown with botanical seed (05/11/2018) in streams in rows at $0.3 \mathrm{~m}$ distance in experimental plots of $16 \mathrm{~m}^{2}(4 \times 4 \mathrm{~m})$.

Prior to sowing, a germination test was carried out and the sowing dose was determined for each treatment (4 $\mathrm{kg} \mathrm{ha}^{-1}$ of viable pure seed); for this purpose, representative samples of the seed were taken from each

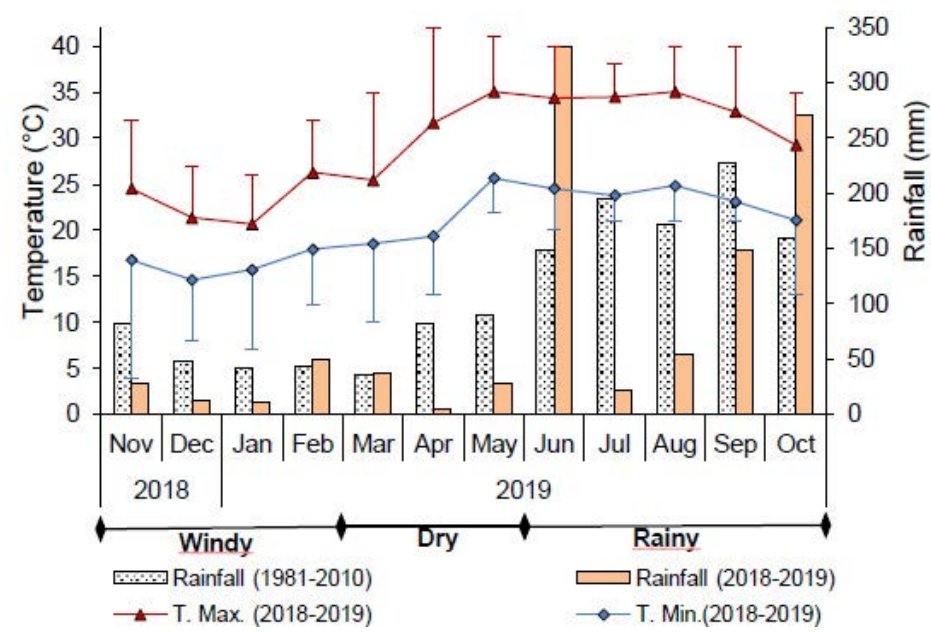

Figure 1. Monthly accumulated precipitation (Preci.) and maximum (Max T.) and minimum (Min. T.) temperature during the period 2018-2019 (1819), in Huejutla de Reyes, Hidalgo. Average information of 29 years (19812010). Source: SMN (2020) 
genotype, and a trial was set up with four repetitions of 100 seeds for each genotype, which were put on newspaper, moistened daily and the germinated seeds were counted, with which the germination percentage was calculated. There was an establishment period of 6 months, in which two uniformity cuts were made at $15 \mathrm{~cm}$ above ground level to stimulate clustering and a rapid establishment of the meadows. Before starting with the sampling in each season, a uniformity cut was made at $15 \mathrm{~cm}$ above the ground and then five samplings were carried out every two weeks. At the center of the furrow, the forage present was harvested periodically in a linear meter (experimental unit). The harvested forage was weighed and a $200 \mathrm{~g}$ subsample was taken, later it was placed in a forced air stove at $65^{\circ} \mathrm{C}$ for $72 \mathrm{~h}$ to dry. The subsamples were weighed before and after drying to determine the dry matter content.

\section{Variables Evaluated and Statistical Analysis}

With the values of the dry matter content, calculations were carried out to determine the accumulation of total dry matter (TDM; $\mathrm{t} \mathrm{ha}^{-1}$ ) using the formula proposed by Hunt (1990) to estimate the CGR ( $\mathrm{kg} \mathrm{ha}^{-1} \mathrm{~d}^{-1}$ ). The variables were analyzed with the GLM procedure by SAS (2003) in a completely randomized design with four repetitions, in an arrangement of measurements repeated over time. The means comparison was carried out using the Tukey test $(p=0.05)$.

$$
Y_{i j k}=\mu+C_{i}+\delta_{i(j)}+S_{k}+(C S)_{i k}+\varepsilon_{i j k}
$$

Where: $Y_{i j k}=$ response variable; $\mu=$ general mean; $C_{i}=$ effect of the cultivar; $\delta_{i(j)}=$ error associated

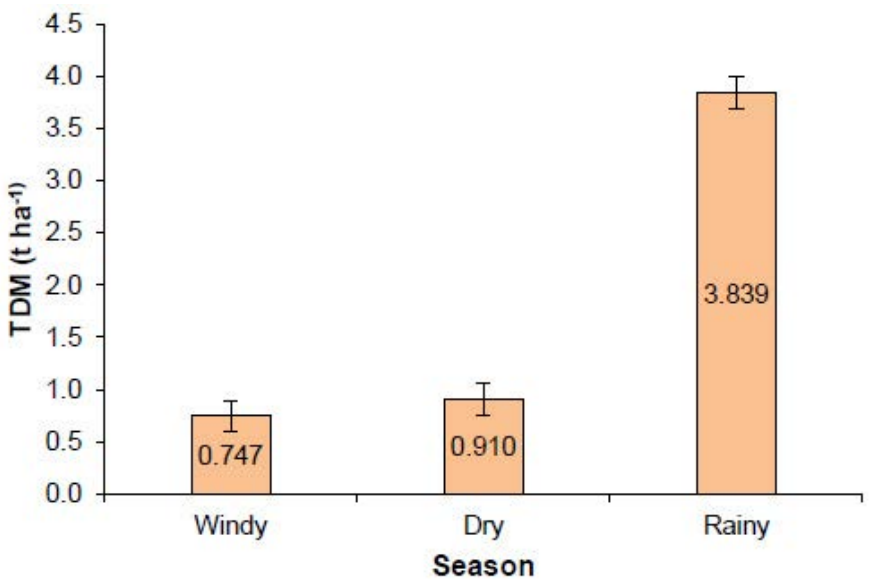

Figure 2. Total dry matter yield (TDM) during the north winds, dry and rainy seasons in Huejutla de Reyes, Hidalgo. The bars represent the least significant difference (Tukey; $p=0.05$ ).

with cultivars; $S_{k}=$ effect of the sampling week; (CS) $i k=$ interaction between the cultivar and the sampling week; $\varepsilon_{i j k}=$ experimental error associated with the sampling week.

\section{RESULTS AND DISCUSSION}

It was observed (Figure 2) that the forage yield was higher $(p<0.05)$ during the rainy season, $3,849 \mathrm{tha}^{-1}$, on average. In contrast, yields were lower ( $p>0.05$ ) during NS and DS (0.747 and $0.910 \mathrm{t} \mathrm{ha}^{-1}$, respectively).

During the NS (November-January) it was observed that the accumulated precipitation was $45 \mathrm{~mm}$, which was $74 \%$ lower (Figure 3), compared to the average accumulation of 29 years (1981-2010) for the same season (173 mm; SMN, 2020). During this season it was observed that the average maximum and minimum
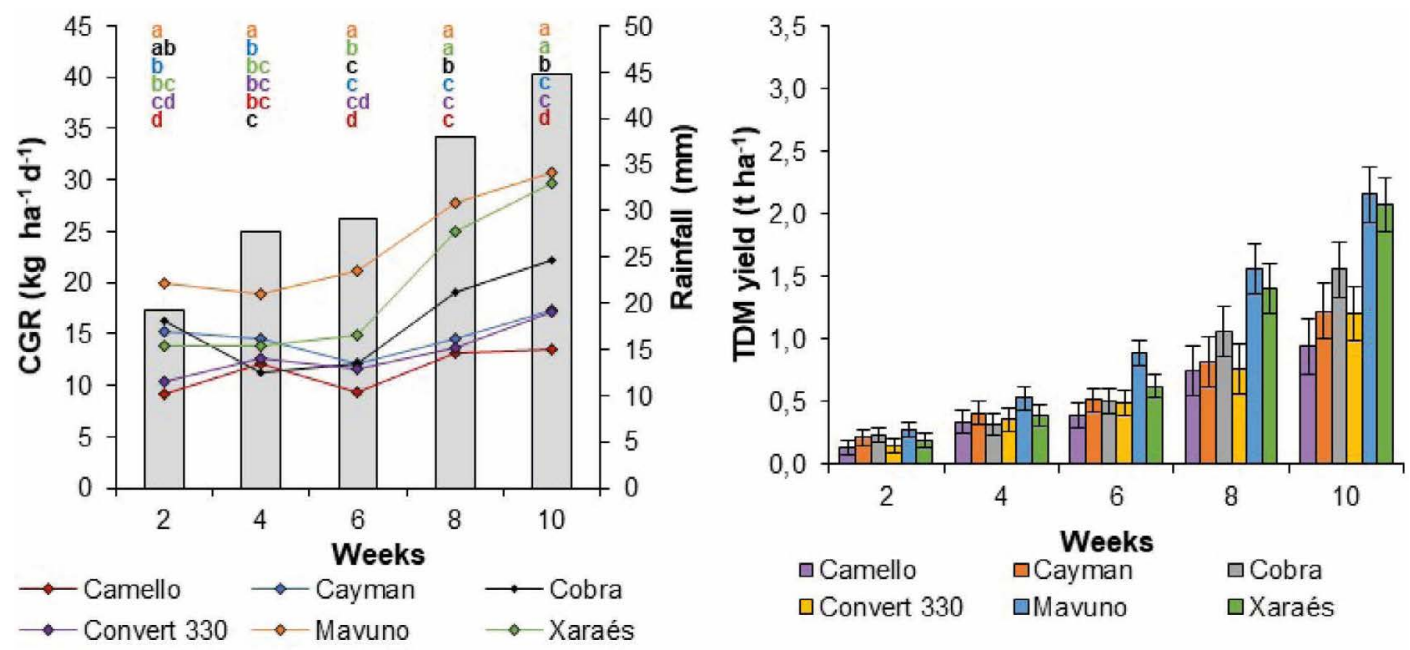

Figure 3. Crop growth rate (CGR) and total dry matter yield (TDM) of cultivars of the genus Urochloa during the north winds season in Huejutla de Reyes, Hidalgo. Different letters between cultivars (a, b, c, d) and the bars in each regrowth age indicate a statistically significant difference (Tukey; $p=0.05$ ). 
temperatures were $22 \pm 6$ and $16 \pm 9{ }^{\circ} \mathrm{C}$, respectively (Figure 1). In this season, the evaluated cultivars presented different growth dynamics, where Mavuno and Xaraés presented on average the highest values of TCC ( $p<0.05), 23.7$ and $19.4 \mathrm{~kg} \mathrm{ha}^{-1} \mathrm{~d}^{-1}$, respectively. In contrast, the Camello, Convert 330 and Cayman cultivars had the lowest CGR, with 11.5, 13.1 and $14.8 \mathrm{~kg} \mathrm{ha}^{-1} \mathrm{~d}^{-1}$, respectively. The average CGR during the NS was 14.1, 13.9, 13.5, 18.9 and $21.8 \mathrm{~kg}$ $\mathrm{ha}^{-1} \mathrm{~d}^{-1}$ at 2, 4, 6, 8 and 10 weeks, respectively (Figure 3).

The average yield of total dry matter (TDM) during the NS was 0.198, $0.389,0.567,1.057,1.525 \mathrm{t} \mathrm{ha}^{-1}$ at $2,4,6,8$ and 10 weeks, respectively. Differences were only observed between the cultivars from the sixth week, where the hybrid Mavuno presented the highest yields $(p<0.05)$ of TDM, 0.886, 1.553 and $2.156 \mathrm{t} \mathrm{ha}^{-1}$ in week 6,8 and 10 , respectively. The Xaraés cultivar only equaled Mavuno at the eighth and tenth weeks. Meanwhile, the hybrid Cobra presented similar yields of TDM that Xaraés. The cultivars that presented the lowest TDM yields during the NS were Cayman, Camello and Convert 330 (Figure 3).

During the DS (March-May) the accumulated precipitation was $35 \mathrm{~mm}$, which was below $83 \%$ (Figure 4) of the average reported for the same season in the study area (207 mm; SMN, 2020). During this season it was observed that the average maximum and minimum temperatures were $31 \pm 9$ and $21 \pm 6{ }^{\circ} \mathrm{C}$, respectively (Figure 1). During this time, the CGRs were 15.4, 21.8, 19.2, 18.9, $26.5 \mathrm{~kg} \mathrm{ha}^{-1} \mathrm{~d}^{-1}$ at 2, 4, 6, 8 and 10 weeks, respectively. There were only differences between the cultivars evaluated in the second and fourth week of regrowth $(p<0.05)$, when the Xaraés, Convert 330, Mavuno and Cayman cultivars presented the highest values (on average), with 20.7 and $26.8 \mathrm{~kg}$ ha ${ }^{-1} d^{-1}$, respectively (Figure 4). On the other hand, the Camello cultivar presented the lowest CGR ( $p<0.05)$ in the same cutting dates, 5.3 and 8.5 $\mathrm{kg} \mathrm{ha} \mathrm{h}^{-1} \mathrm{~d}^{-1}$, respectively. From the sixth to the tenth week, all cultivars presented similar ( $p>0.05)$ CGR (Figure 4). In this season, only significant differences $(p<0.05)$ were observed between the cultivars for the TDM variable in the fourth, eighth and tenth weeks. The most outstanding were Cayman (meaning week 10), Cobra (meaning week 4), Convert 330, Mavuno and Xaraés (Figure 4), which on average presented 0.685, 1.145 and 1.935 t ha $^{-1}$ at 4,8 and 10 weeks, respectively. In contrast, the Camello hybrid was the one that presented the lowest TDM values, $0.237,0.618$ and $1.469 \mathrm{t} \mathrm{ha}^{-1}$, respectively, for the aforementioned regrowth ages. The TDM yield for this season was 0.216, 0.610, 0.808, 1.057 and $1.857 \mathrm{tha}^{-1}$ at 2, 4, 6, 8 and 10 weeks, respectively (Figure 4).

During the rainy season (June-August) the accumulated precipitation was $304 \mathrm{~mm}$, which was 41\% lower, compared to the average reported for the same season $(517 \mathrm{~mm}$ ) in the place where the evaluation was carried out (SMN, 2020). Likewise, it was observed that the average maximum and minimum temperatures were $35 \pm 5$ and $24 \pm 4{ }^{\circ} \mathrm{C}$, respectively (Figure 1). During this season the highest growth dynamics was observed in the


Figure 4. Crop growth rate (CGR) and total dry matter yield (TDM) of cultivars of the Urochloa genus during the dry season in Huejutla de Reyes, Hidalgo. Different letters between cultivars ( $a, b, c, d)$ and the bars at each regrowth age indicate a statistically significant difference (Tukey; $p=0.05$ ) 

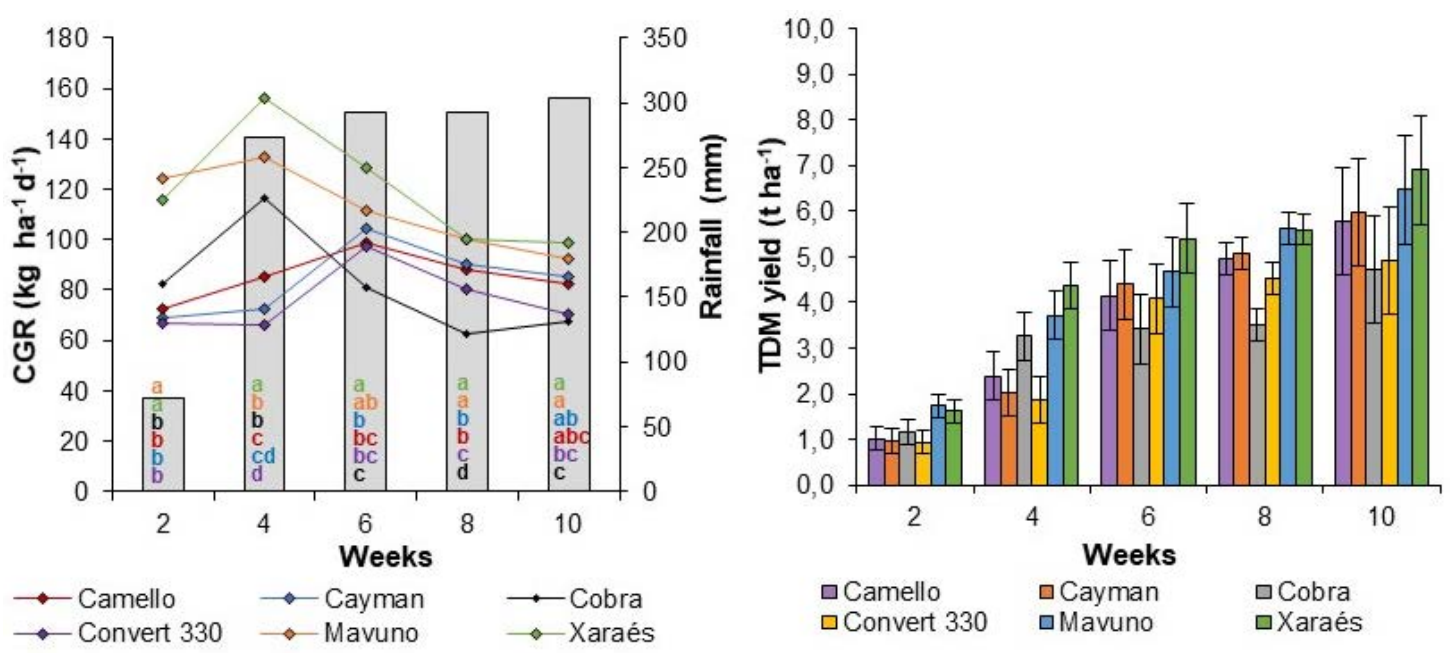

Figure 5. Crop growth rate (CGR) and total dry matter yield (TDM) of cultivars of the Urochloa genus during the rainy season in Huejutla de Reyes, Hidalgo. Different letters between cultivars (a, b, c, d) and the bars at each regrowth age indicate a statistically significant difference (Tukey; $p=0.05$ ).

grasses evaluated. In this sense, the CGRs were 88.4, 105.0, 103.6, 87.1, 82.7 $\mathrm{kg} \mathrm{ha}^{-1} \mathrm{~d}^{-1}$ at 2, 4, 6, 8 and 10 weeks, respectively. In the second and fourth week of regrowth, the Xaraés and Mavuno cultivars presented the highest CGRs $(p<0.05)$, which on average were 119.8 and $144.7 \mathrm{~kg} \mathrm{ha}^{-1} \mathrm{~d}^{-1}$, respectively (Figure 5).

On the contrary, Camello, Convert 330 and Cayman, presented the lowest values in the CGR $(p<0.05)$, which, on average were 69.5 and $74.7 \mathrm{~kg} \mathrm{ha}^{-1} \mathrm{~d}^{-1}$, respectively, for the aforementioned regrowth ages (Figure 5). It should be noted that the Cobra cultivar, during the first two regrowth ages (2 and 4 weeks), presented CGR similar to those of Xaraés and Mavuno; however, from the sixth to the tenth week, these values decreased considerably, ranging between 62.7 and $81.2 \mathrm{~kg} \mathrm{ha}^{-1}$ $\mathrm{d}^{-1}$. The greater growth dynamic observed during the rainy season was reflected in the greater accumulation of TDM. In this sense, yields of 1,238, 2,939, 4,350, 4,880 and 5,790 t ha $^{-1}$ were obtained at 2, 4, 6, 8 and 10 weeks, respectively. At 2 and 4 weeks of regrowth, the Xaraés and Mavuno cultivars presented the highest TDM yields $(p<0.05$ ), with values (on average) of 1,677 and $4,051 \mathrm{t}$ $\mathrm{ha}^{-1}$, respectively. From the sixth week on, the Camello, Cayman, Mavuno and Xaraés cultivars presented similar TDM yields, which, on average, were 4,652, 5,312 and 6,278 t ha $^{-1}$, respectively (Figure 5).

The CGR or absolute growth rate (AGR), is the increase in the dry matter of the plant or of each of its organs per unit area that it occupies in the soil, per unit of time (Hunt, 1990), behavior which was observed in Figures 3 to 5. The reduction in CGR during NS and DS was the result of the low availability of moisture $(45$ and $35 \mathrm{~mm}$, respectively). In addition to this, during the NS there were minimum temperatures that were below $10^{\circ} \mathrm{C}$ (Figure 1), which affected the growth of the grasses. It has been documented that in tropical grasses, as is the case of the grasses evaluated in this study, when the temperature falls below $15{ }^{\circ} \mathrm{C}$, respiration and photosynthesis are interrupted, thus inevitably stopping plant growth (Durán et al., 2011). In contrast to the two seasons mentioned above, during the rainy season there was greater growth dynamics. This was mainly influenced by the availability of moisture (304 mm of precipitation) and the relatively high temperatures, which were 24 and $35^{\circ} \mathrm{C}$, average minimum and maximum temperatures, respectively; these conditions favored active growth of the forage (Cruz et al., 2011; Martínez-López et al., 2014; Santos et al., 2014).

Temperature is a factor that directly affects the growth of plants. The minimum threshold temperature of most tropical grasses has been reported to be $15^{\circ} \mathrm{C}$ (Durán et al., 2011; Berone, 2016). However, it has been reported that the Xaraés cultivar presents a minimum threshold temperature of $12.4^{\circ} \mathrm{C}$ (Silva et al., 2012), a characteristic that allowed it to have higher CGR and accumulation of TDM during NS. The growth of the Urochloa cultivars was affected by the conditions that were present during the north winds season; mainly, a decrease in temperature and high cloudiness (Hernández et al., 1990; Martínez et al., 2008). The latter directly affects the photosynthesis process, since it is closely 
related to photosynthetically active radiation (Mishra et al., 2010), which was reflected in the lower accumulation of CGR. The highest growth dynamics occurred during the RS, as a result of the active growth of the grass (Castro et al., 2013). Likewise, during this season there was an increase in the temperature, which accelerates the growth of the plant and this can cause senescence of the forage to be earlier (Santos et al., 2014). In addition, during this season, there was greater availability of humidity, and also temperatures above $18^{\circ} \mathrm{C}$, which allowed the growth of the grasses. It has been indicated that in order not to affect the growth of forage grasses, in addition to the humidity present in the soil, there should be temperatures above $15^{\circ} \mathrm{C}$, which is the minimum threshold temperature of most tropical grasses (Mendonça and Rassini, 2006; Durán et al., 2011). The forage production of cultivars of the Urochloa genus was variable during the year, since it depended on the environmental conditions present during each season. It has been reported that the annual forage production of this genus is distributed as follows in the three seasons: from 13 to $22 \%$ in the NS, from 8 to $12 \%$ in the DS, and from 66 to $79 \%$ in the RS (Martínez et al., 2008; Cab et al., 2008); which are similar to the yields reported in this study.

\section{CONCLUSIONS}

In the conditions where the experiment was carried out there are difficulties for forage production, mainly during NS and DS. The Xaraés, Mavuno and Cayman cultivars showed greater growth and accumulation of total dry matter; therefore, they can be an option for the livestock production that is carried out in warm sub-humid conditions. It is worth mentioning that this evaluation was only carried out during the period of one year, which was atypical compared to the average values of the climatological events for the place of study.

\section{ACKNOWLEDGMENTS}

Our gratitude to the Technological Institute of Huejutla (ITH), and to PhD. Pánfilo Saldaña Campos, for the support provided for this research. Also, to Alicia Lucas de la Cruz, María de la Luz Hernández Casas and Alan R. Alvarado Sánchez, students of the ITH, who helped us in the field work

\section{REFERENCES}

Berone, G. D. (2016). Leaf expansion and leaf turnover of perennial C4 grasses growing at moderately low temperatures. Revista de la Facultad de Ciencias Agrarias, 48(2):69-82.

Cab, F., Enriquez, J., Pérez, J., Hernández, A., Herrera, J., Ortega, E., \& Quero, A. (2008). Potencial productivo de tres especies de Brachiaria en monocultivo y asociadas con Arachis pinto: en Isla, Veracruz. Técnica Pecuaria en México, 46:317-332.

Castro, R., Hernández, A., Ramírez, O., Aguilar, G., Enríquez, J. F., \& Mendoza, S. I. (2013). Crecimiento en longitud foliar y dinámica de población de tallos de cinco asociaciones de gramíneas y leguminosa bajo pastoreo. Revista Mexicana de Ciencias Pecuarias, 4(2):201-215

Cruz, A., Hernández, A., Enríquez, J., Gómez, A., Ortega, E., \& Maldonado, N. (2011). Producción de forraje y composición morfológica del pasto Mulato (Brachiaria híbrido 36061) sometido a diferentes regímenes de pastoreo. Revista Mexicana de Ciencias Pecuarias, 2:429-443.

Durán, N., Ruiz, J. A., González, D. R., Núñez, G., Padilla, F. J., \& Contreras, S. H. (2011). Temperaturas cardinales de desarrollo en la etapa siembra-emergencia de 11 pastos forrajeros. Revista Mexicana de Ciencias Pecuarias, 2(3):347-357.

Garay, J. R., Joaquín, S., Zárate, P., Ibarra, M. A., Martínez, J. C., González, R. P., \& Cienfuegos, E. G. (2017). Dry matter accumulation and crude protein concentration in Brachiaria spp. cultivars in the humid tropics of Ecuador. Tropical Grasslands-Forrajes Tropicales, 5(2):66-76.

García, E. (2004). Modificaciones al sistema de clasificación climática de Köppen. México: Instituto de Geografía-UNAM

Hernández, T., Valles, B., \& Castillo, E. (1990). Evaluación de gramíneas y leguminosas forrajeras en Veracruz, México. Pasturas Tropicales, 2:29-33.

Hunt, R. 1990. Basic growth analysis: Plant growth analysis for beginners. England: Unwin Hyman.

INEGI. 2017. Anuario estadístico y geográfico de Hidalgo 2017. México: Instituto Nacional de Estadistica y Geografía.

INEGI. 2018. Mapa digital de México V 6.3.0. En: http://gaia.inegi.org.mx/mdm6/?v=bGF00jlw Ljk1MTI2LGxvbjotOTkuMDAwODMsejo1LGw6Y2Fncm98YzEwM3A. Fecha de consulta: 18/03/2020.

Martínez, D., Hernández, A., Enríquez, J. F., Pérez, J., González, S. S., \& Herrera, J. G. (2008). Producción de forraje y componentes del rendimiento de pasto Brachiaria humidicola CIAT 6133 con diferente manejo de defoliación. Técnica Pecuaria en México, 46:427438

Martínez-López, J. R., Gutiérrez-Ornelas, E., Barrera-Silva, M. A., \& Retes-López, R. (2014). Simulación estocástica para praderas de pasto buffel (Cenchrus ciliaris L.) en Marín, N. L., México. Tropical and Subtropical Agroecosystems, 17:87-104.

Mendonça, F. C., \& Rassini, J. B. (2006). Temperatura-base inferior e estacionalidade de produção de gramíneas forrageiras tropicais. Brasil: Embrapa Ganadería Sudeste.

Mishra, A. K., Tiwari, H. S., \& Bhatt, R. K. 2010. Growth, biomass production and photosynthesis of Cenchrus ciliaris L. under Acacia tortilis (Forssk.) Hayne based silvopastoral systems in semiarid tropics. Journal of Environmental Biology, 31(6):987-993.

Pizarro, E., Hare, M., Mutimura, M., \& Changjun, B. 2013. Brachiaria hybrids: potential, forage use and seed yield. Tropical Grasslands-Forrajes Tropicales, 1(1):31-35 
Santos, R. M., Voltolini, T. V., Angelotti, F., Aidar, S. T., \& Chaves, A. R. M. (2014). Productive and morphogenetic responses of buffe grass at different air temperatures and $\mathrm{CO}_{2}$ concentrations. Revista Brasileira de Zootecnia, 43(8):404-409.

SAS. 2003. The SAS 9.1 for Windows. SAS Institute Inc. Cary, North Carolina. USA

Silva, E. A., Silva, W. J., Barreto, A. C., Junior, A. B. O., Paes, J. M. V., Ruas, J. R. M., \& Queiroz, D. S. (2012). Dry matter yield, thermal sum and base temperatures in irrigated tropical forage plants. Revista Brasileira de Zootecnia, 41(3): 574-582.

SMN. 2020. Normales climatológicas. Información Climatológica por Estado. Servicio Metrológico Nacional. En: https://smn.cna.gob. $\mathrm{mx} /$ es/informacion-climatologica-por-estado? estado=hgo Fecha de consulta: 10/04/2019.

Vendramini, J., Sollenberger, L., Soares, A., Da Silva, W., Sanchez, J., Valente, A., Aguiar, A., \& Mullenix, M. (2014). Harvest frequency affects herbage accumulation and nutritive value of Brachiaria grass hybrids in Florida. Tropical Grasslands-Forrajes Tropicales, 2(2):197-206

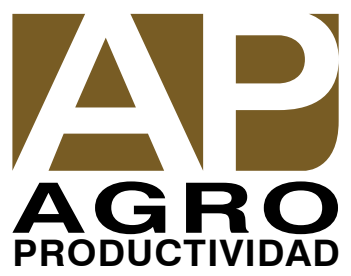

